\title{
PENGEMBANGAN APLIKASI \\ KAMUS BAHASA BIMA - BAHASA INDONESIA MENGGUNAKAN ALGORITMA LEVENSHTEIN DISTANCE SEBAGAI SPELL CHECKER BERBASIS ANDROID
}

\author{
Yunita Purnama Sari ${ }^{1}$ Gede Aditra Pradnyana ${ }^{2}$, I Made Agus Wirawa ${ }^{3}$, \\ Program Studi Pendidikan Teknik Informatika \\ Universitas Pendidikan Ganesha \\ E-mail : yunitapurnamasari497@ymail.com ${ }^{1}$, gede.aditra@undiksha.ac.id ${ }^{2}$, imade.aguswirawan@ undiksha.ac.id $^{3}$
}

\begin{abstract}
Abstrak - Bahasa Bima merupakan salah satu identitas kebudayaan masyarakat Bima. Pengaruh perkembangan globalisasi membuat Bahasa Bima semakin terpinggirkan dan seolah-olah menjadi bahasa "asing" bagi masyarakat Bima sendiri. Bahasa Bima sebagai bahasa ibu wajib dilestarikan, salah satu upayanya adalah dengan mengembangkan aplikasi kamus bahasa Bima.

Tujuan dari penelitian ini adalah: (1) Untuk mengetahui bagaimana perancangan terhadap Aplikasi Kamus Bahasa Bima - Bahasa Indonesia Menggunakan Algoritma Levenshtein Distance Sebagai Spell Checker Berbasis Android. (2) Untuk mengetahui bagaimana implementasi terhadap Aplikasi Kamus Bahasa Bima - Bahasa Indonesia Menggunakan Algoritma Levenshtein Distance Sebagai Spell Checker Berbasis Android. Metode penelitian yang digunakan adalah penelitian dan pengembangan dengan model waterfall. Aplikasi dikembangkan dengan menerapkan algoritma Levenshtein Distance, yakni algoritma pencarian untuk menentukan jumlah perbedaan string pada dua buah kata/kalimat yang ditemukan oleh Vladimir Levenshtein. Aplikasi akan menggunakan database SQLite agar dapat digunakan secara offline. Hasil penelitian ini berupa aplikasi kamus Bahasa Bima - Bahsa Indonesia yang dapat dipasang pada smartphone Android. Dengan adanya aplikasi ini diharapkan mampu menjaga kelestarian Bahasa Bima serta mempermudah bekomunikasi antara masyarakat Bima dan lainnya.
\end{abstract}

Kata kunci: Kamus, Bahasa Bima-Indonesia, Levenshtein Distance, Android

Abstract- Bima language is one of the cultural identities of the Bima community. The influence of the development of globalization makes Bima's language increasingly marginalized and seems to be a "foreign" language for the Bima community itself. Bima language as a mother tongue must be preserved, one of its efforts is to develop a Bima language dictionary application.

The objectives of this study are: (1) To find out how to design the application of the Bima Language Dictionary Indonesian Language Using the Levenshtein Distance Algorithm as an Android-based Spell Checker. (2) To find out how the application of the Bima Language Dictionary
Application - Indonesian Language Using the Levenshtein Distance Algorithm As an Android-Based Spell Checker. The research method used is research and development with the waterfall model. The application was developed by applying the Levenshtein Distance algorithm, the search algorithm to determine the number of string differences in the two words / sentences found by Vladimir Levenshtein. The application will use the SQLite database so that it can be used offline. The results of this study are in the form of a Bima-Bahsa Indonesian dictionary application that can be installed on an Android smartphone. With this application, it is expected to be able to preserve the preservation of Bima Language and facilitate communication between Bima and others.

\section{Keywords: Dictionary, Bima-Indonesian Language,} Levenshtein Distance, Android

\section{PENDAHULUAN}

Indonesia merupakan Negara kesatuan yang terdiri dari berbagai daerah yang memiliki Suku, Ras, dan Bahasa yang berbeda-beda. Kemajemukan yang dimiliki Negara Indonesia dari satu sisi merupakan sebuah kekayaan yang hakiki, namun di sisi yang lain, merupakan tugas berat bagi pemerintah untuk menjaga keberagaman yang dimiliki. Salah satu dari kekayaan itu adalah Bahasa Daerah, dikutip dari Ethnoloque (2012) disebutkan bahwa terdapat 726 bahasa di Indonesia. penting sebagai pendidikan dasar bagi anak untuk mempelajari bahasa kedua (Sindonews, 2014).

Bahasa Daerah yang ada di Indonesia salah satunya adalah Bahasa Bima. Bahasa Bima atau nggahi mbojo digunakan oleh masyarakat umum di Bima sebagai alat komunikasi sehari-hari dan juga digunakan saat kegiatan adat istiadat. Pengaruh perkembangan globalisasi membuat masyarakat Bima mengalami perubahan pola kehidupan dan bahasa sehari-hari. Bahasa Bima semakin terpinggirkan dan seolah-olah menjadi Bahasa "asing" bagi masyarakat Bima sendiri. Keberadaan Bahasa Bima sebagai Bahasa Ibu wajib dilestarikan, demi menunjang komunikasi serta identitas sebagai masyarakat Bima (Sumatika, 2015)

Salah satu cara mempertahankan budaya daerah khususnya Bahasa Bima agar terhindar dari kepunahan yaitu dengan membuat Kamus Bahasa Bima. Pemilihan kamus sebagai salah satu buku referensi, memuat daftar kata-kata 
yang berasal dari suatu Bahasa, disusun secara alfabetis, disertai keterangan penggunaan kata. Selain menerangkan arti kata, kamus juga merupakan suatu pedoman mengenai sebutan/istilah, asal-usul (etimologi) sesuatu perkataan yang digunakan untuk menerjemahkan suatu Bahasa.

Aplikasi ini akan dikembangkan pada platform Android menggunakan bahasa pemrograman java. Android merupakan platform mobile yang lengkap, terbuka dan bebas (Safaat, 2012). Dalam perkembangannya, Android tergolong platform yang masih berusia muda, namun popularitas Android mampu menyaingi platform smartphone lainnya. Android menempati peringkat teratas pangsa pasar di bulan November 2015 dengan angka 53,1 persen, diikuti oleh Apple dengan 43,1 persen. Selebihnya 3,8 persen, diambil oleh Windows Phone 2,8 persen dan BlackBerry 1,0 persen (Comscore, 2016).

Algortima yang digunakan dalam pengembangan aplikasi ini adalah algoritma Levenshtein Distance, yakni algoritma untuk menentukan jumlah perbedaan string pada dua buah kata/kalimat yang ditemukan oleh Vladimir Levenshtein, seorang ilmuwan Rusia pada tahun 1996. Algoritma ini digunakan secara luas dalam berbagai bidang, misalnya mesin pencari, pengecek ejaan (spell checking), pengenal pembicaraan (speech recognition), pengucapan dialek, analisis DNA, predeksi pemalsuan, dan lain-lain. Seperti yang diterapkan pada sebuah aplikasi yang dikembangkan dalam penelitian yang berjudul Aplikasi Pendeteksi Kemiripan Isi Teks Dokumen Menggunakan Metode Levenshtein Distance (Ariyani, 2016). Hasil akhir yang diperoleh dari penerapan algoritma Levenshtein Distance dalam sistem ini adalah memberikan presentase nilai similarity antara dua buah dokumen teks.

Berdasarkan paparan tersebut, penulis termotivasi untuk mengembangkan aplikasi kamus tersebut melalui penelitian berjudul "Pengembangan Aplikasi Kamus Bahasa Bima Bahasa Indonesia Menggunakan Algoritma Levenshtein Distance Sebagai Spell Checker Berbasis Android”.

\section{KAJIAN TEORI}

A. Kamus

Menurut Alwi (2003:10) kamus merupakan khazanah perbendaharaan kata suatu Bahasa yang menggambarkan tingkat peradaban bangsa pemiliknya. Ia berfungsi untuk membantu seseorang mengenal perkataan baru. Selain menerangkan maksud kata, kamus juga mungkin mempunyai pedoman sebutan, asal-usul (etimologi) sesuatu perkataan dan juga contoh penggunaan bagi sesuatu perkataan.

\section{B. Algoritma Levensthein Distance}

Levensthein Distance ditemukan oleh seorang ilmuan asal Rusia bernama Vladimir Levensthein pada tahun 1965, algoritma ini juga disebut dengan algoritma Edit Distance. Levensthein Distance adalah suatu matriks untuk mengukur jumlah perbedaan antara dua string. Levensthein Distance dua buah string adalah jumlah minimum operasi yang dibutuhkan untuk mengubah satu string (source string) menjadi string yang lain (target string), dimana suatu operasi melibatkan penyisipan (insertion), penghapusan (deletion), dan penggantian (substitution) dari suatu karakter tunggal. Perhitungan edit Distance didapat dari matriks yang digunakan untuk menghitung jumlah perbedaan string antara dua string. Perhitungan jarak antara dua string ini ditentukan dari jumlah minimum operasi perubahan untuk membuat string A menjadi String B.

\section{Unified Modelling Language (UML)}

Unified Modelling Language (UML) adalah keluarga notasi grafis yang didukung oleh metamodel tunggal, yang membantu pendeskripsian dan desain sistem perangkat lunak, khususnya sistem yang dibangun menggunakan pemrograman berorientasi obyek (OOP). Menurut Munawar (2005:17), Unified Modelling Language (UML) adalah salah satu alat bantu yang sangat handal di dunia pengembangan sistem yang handal berorieniasi objek.

\section{Bahasa Indonesia}

Bahasa Indonesia adalah alat komunikasi yang dipergunakan oleh masyarakat Indonesia untuk keperluan sehari-hari, misalnya belajar, bekerja sama, dan berinteraksi. Bahasa Indonesia merupakan bahasa Nasional dan bahasa resmi di Indonesia. Bahasa Nasional adalah bahasa yang menjadi standar di Negara Indonesia. Sebagai bahasa Nasional, bahasa Indonesia tidak mengikat pemakainya untuk sesuai dengan kaidah dasar. Bahasa Indonesia digunakan secara non resmi, santai dan bebas.

\section{E. Bahasa Bima}

Bahasa Bima adalah bahasa yang digunakan oleh masyarakat yang tinggal di bagian Timur Pulau Sumbawa (Syamsudin, 1996: 13). Umumnya bahasa Bima disebut dengan Nggahi Mbojo oleh penutur dan masyarakat Bima. Berdasarkan pengamatan di Bima, selain bahasa Bima, ada juga bahasa yang digunakan oleh masyarakat terpencil lainnya yang berada ditengah-tengah masyarakat Bima lainnya.

\section{F. Android}

Android merupakan sistem operasi bebasis Linux yang digunakan untuk perangkat mobile seperti smartphone (Agustina, 2017). Sejalan dengan hal tersebut, Android adalah sistem operasi untuk perangkat mobile yang mencakup sistem operasi, middleware, dan aplikasi (Safaat, 2015:1). Awalnya android merupakan sebuah perusahaan yang kemudian diakuisisi Google pada tahun 2000. Setelah diakui, sistem Android hanya dikembangkan untuk kebutuhan internal Google dan belum belisensi open source.

G. Android Studio

Android Studio merupakan sebuah Integrated Development Environment (IDE) khusus untuk membangun 
aplikasi yang berjalan pada platform android dan bersifat open source atau gratis. Peluncuran Android Studio ini diumumkan oleh Google pada 16 mei 2013 pada event Google I/O Conference untuk tahun 2013. Sejak saat itu, Android Studio mengantikan Eclipse sebagai IDE resmi untuk mengembangkan aplikasi Android.

\section{H. SQlite}

SQLite merupakan sebuah sistem manajemen basis data relasional bersifat ACID-compliant dan memiliki ukuran pustaka kode yang relative kecil, ditulis dalam bahasa $\mathrm{C}$. SQLite adalah perpustakaan perangkat lunak yang menerapkan engine database SQL secara mandiri, tanpa memerlukan server, tanpa perlu melakukan konfigurasi, dan bersifat transaksional. SQLite adalah engine database SQL yang paling banyak digunakan di dunia. SQLite merupakan proyek yang bersifat public domain yang dikerjakan oleh D. Richard Hipp (Yudana, 2017).

\section{METODOLOGI PENELITIAN}

Pengembangan Aplikasi Kamus Bahasa Bima - Bahasa Indonesia Menggunakan Algoritma Levenshtein Distance Berbasis Android merupakan penelitian Research and Development $(R \& D)$. Menurut Brog and Gall dalam Sugiyano (2007), Research and Development merupakan metode penelitian yang digunakan untuk mengembangkan atau memvalidasi produk-produk yang digunakan dalam pendidikan dan pembelajaran. Research and Development digunakan untuk menghasilkan produk tertentu dan menguji keefektifan produk tersebut (Sugiyono, 2007).

Penelitian yang akan dilakukan oleh peneliti berfokus pada proses pengembangan, verifikasi dan validasi perangkat lunak yang dikembangkan. Metode pengembangan perangkat lunak yang dilakukan peneliti mengacu pada model yang ada pada Software Development Life Cycle (SDLC). Model SDLC yang digunakan dalam pengembangan penelitian ini adalah model waterfall dan pemodelannya menggunakan UML (Unified Modelling Language). Beberapa tahap penelitian yang akan dilakukan dalam penelitian ini dapat dilihat pada gambar di bawah ini.

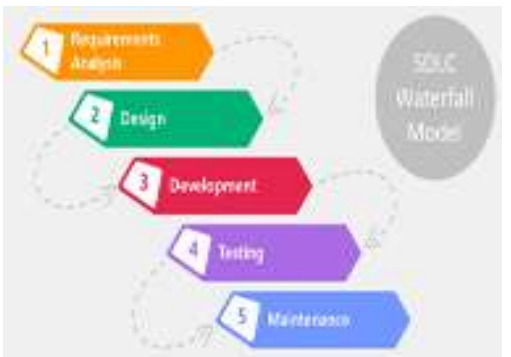

Gambar 1. SDLC Waterfall Model (xbsoftware.com)

\section{A. PROSEDUR PELITIAN}

1. Tahap Analisis

Tahap analisis merupakan tahapan yang paling awal. Tahapan ini akan sangat menentukan dan menjadi dasar untuk tahapan-tahapan berikutnya, dalam hal ini terdapat dua hal yaitu:

a. Analisis Masalah

Analisis masalah dilakukan untuk mengetahui masalah apa yang menjadi latar belakang dari penelitian. Masalah yang diangkat dalam penelitian ini yakni keberadaan Bahasa Bima yang sudah mulai ditinggalkan dengan banyaknya masyarakat pendatang

b. Analisis Kebutuhan

Analisis kebutuhan dilakukan untuk mengetahui kebutuhan yang dibutuhkan dalam proses pengembangan. Pada tahap ini akan dipaparkan mengenai tahapan awal pengembangan perangkat lunak, yaitu meliputi kebutuhan perangkat lunak, tujuan pengembangan perangkat lunak, masukan dan keluaran perangkat lunak dan model fungsional perangkat lunak.

\section{Perancangan}

Perancangan peranglat lunak merupakan tahap selanjutnya setelah melakukan analisis perangkat lunak. Rancangan perangkat lunak yang dibuat, nantinya akan menjadi panduan pengembangan pada tahap implementasi.

\section{Implementasi}

Implementasi merupakan tahapan selanjutnya setelah tahap perancangan. Implementasi perangkat lunak yang terdiri dari lingkungan implementasi perangkat lunak, batasan impelentasi perangkat lunak, implementasi arsitektur perangkat lunak, implementasi struktur data perangkat lunak, implementasi layer antarmuka perangkat lunak.

4. Pengujian

Tahap selanjutnya setelah implementasi perangkat lunak adalah tahap pengujian perangkat lunak. Tahap ini merupakan tahap dimana rancangan aplikasi yang telah dibuat, diimplementasikan, untuk selanjutnya diuji apakah semua komponen dari aplikasi sudan berjalan sesuai dengan fungsinya.

\section{HASIL DAN PEMBAHASAN}

A. HASIL

Berdasarkan metode penelitian yang telah dipaparkan sebelumnya, beberapa tahap penelitian yang dilakukan dalam penelitian ini yaitu bergerak maju mulai dari tahap analisis, perancangan, implementasi dan pengujian. Hasil dari setiap tahapan penelitian pada pengembangan Aplikasi Kamus Bahasa Bima - Bahasa Indonesia Menggunakan Algoritma Levensthein Distance Sebagai Spell Checker Berbasis Android adalah sebagai bertikut. 


\section{Analisis Masalah}

Analisis masalah dilakukan untuk menggetahui masalah apa yang terjadi latar belakang dari penelitian. Masalah yang diangkat dalam penelitian ini yakni keberadaan Bahasa Bima yang sudah mulai ditinggalkan dengan banyaknya masyarakat pendatang. Saat ini upaya yang dilakukan oleh masyarakat dan pemerintah untuk melestarikan Bahasa Bima sendiri dinilai masih kurang. sehingga penelti membuat aplikasi yang dapat menerjemahkan kata ke dalam Bahasa Bima, di harapkan nantinya bisa membantu melestarikan Bahasa bima serta membantu masyarakat bima untuk berkomunikasi.

\section{Analisis Perangkat Lunak}

Tahap analisis perangkat lunak ini merupakan tahap pertama dalam model waterfall yaitu tahap analisis kebutuhan (requirement analysis). Analisis kebutuhan dilakukan untuk mengetahui kebutuhan yang dibutuhkan dalam proses pengembangan. Pada tahap ini akan dipaparkan mengenai tahapan awal pengembangan perangkat lunak, yaitu meliputi kebutuhan perangkat lunak, tujuan pengembangan perangkat lunak, masukan dan keluaran perangkat lunak dan model fungsional perangkat lunak. perangkat lunak digunakan untuk menjelaskan bagaimana gambaran umum dari perangkat lunak yang akan dikembangkan.

a. Kebutuhan Perangkat Lunak

1) Kebutuhan Fungsional

Berdasarkan analisis yang dilakukan terhadap prosesproses yang dapat diimplementasikan oleh Aplikasi Kamus Bahasa Bima-Bahasa Indonesia Menggunakan Algoritma Levensthein Distance sebagai Spell Cheker Berbasis Android adalah sebagai berikut. (1) Pengguna dapat menampilkan splash screen. (2) Pengguna dapat menampilkan halaman utama yang menyediakan menu utama pada aplikasi dan menampilkan halaman penerjemah. (4) Pengguna dapat menerjemahkan kata menggunakan algoritma levenhstein distance. (5) Pengguna dapat menerjemahkan kata dari bahasa Bima ke bahasa Indonesia maupun Bahasa Indonesia ke Bahasa Bima. (6) Aplikasi dapat memeriksa kesalahan pengetikan pada kata yang dimasukan oleh pengguna menggunakan levensthein distance serta menampilkan rekomendasi kata yang mungkin dimaksud oleh pengguna. (7) Pengguna dapat menampilkan halaman about untuk melihat informasi tentang aplikasi.

2) Kebutuhan Non-Fungsional

Kebutuhan non-fungsional dari Aplikasi Kamus Bahasa Bima - Bahasa Indonesia Menggunakan Algoritma Levensthein Distance Sebagai Spell Checker Berbasis Android antara lain: (1) Desain antarmuka aplikasi dirancang sedemikian rupa agar memudahkan pengguna aplikasi untuk menggunakan dan mudah dipahami (user usibility). (2) Aplikasi ini dirancang untuk dapat dijalankan pada platform Andorid

b. Tujuan Pengembangan Perangkat Lunak
Aplikasi Kamus Bahasa Bima - Bahasa Indonesia Menggunakan Algoritma Levensthein Distance Sebagai Spell Checker Berbasis Android ini diharapkan mampu memenuhi proses-proses sebagai berikut. (1) Mampu menampilkan splash screen. (2) Mampu menampilkan halaman utama yang menyediakan penerjemahan pada aplikasi. (3) Mampu menerjemahkan kata menggunakan algoritma levensthein distance. (3) Mampu menerjemahkan kata dari Bahasa Bima ke Bahasa Indonesia serta dari Bahasa Indonesia ke Bahasa Bima. (4) Mampu memerikasi kesalahan pengetikan pada kata yang dimasukan oleh pengguna menggunakan levensthein distance serta menampilkan rekomendasi kata yang mungkin dimaksud oleh pengguna. (5) User dapat menampilkan halaman about untuk melihat informasi tentang aplikasi.

c. Masukan dan Keluaran Perangkat Lunak.

1) Masukan Perangkat Lunak

Aplikasi Kamus Bahasa Bima - Bahasa Indonesia Menggunakan Algoritma Levensthein Distance Sebagai Spell Checker Berbasis Android, masukannya berupa kata (teks) yang diketik langsung oleh pengguna.

2) Keluaran Perangkat Lunak

Keluaran dari perangkatt lunak Aplikasi Kamus Bahasa Bima - Bahasa Indonesia Menggunakan Algoritma Levensthein Distance Sebagai Spell Checker Berbasis Android yaitu berupa teks hasil terjemahan dalam bentuk kata atau beberapa kata.

d. Model Fungsional Perangkat Lunak

Model fungsional perangkat lunak digunakan untuk menjelaskan bagaimana gambaran umum dari perangkat lunak yang akan dikembangkan. Gambaran umum yang dibuat divisualisasikan dalam bentuk gambar ataupun komunikasi agar dapat dimengerti oleh pihak lain. Gambaran umum algoritma levensthein distance pada penelitian ini ditampilkan dalam bentuk diagram flowchart sebagai berikut

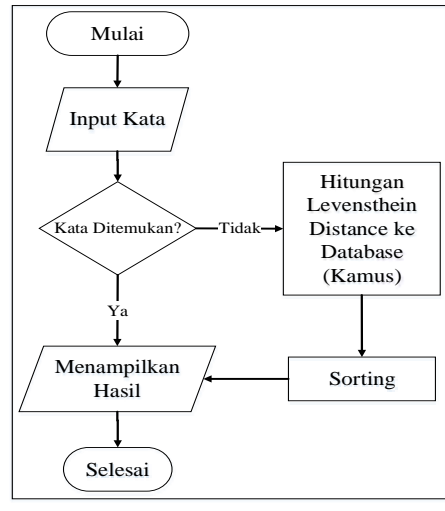

Gamabr 2. Flowchart Aplikas

e. Use Case Diagram

Use Case mendeskripsikan interaksi tipikal antara pengguna sistem dengan sistem itu sendiri, dengan memberi sebuah narasi tentang bagaimana sistem tersebut digunakan. 
Use case diagram digunakan untuk mengetahi fungsi apa saja yang ada di dalam sebuah sistem aplikasi. Use case diagram menggambarkan seluruh aktifitas dalam sistem dari sudut pandang pengamatan luar dan menggambarkan ruang lingkup suatu aplikasi secara garis besarnya. Aliran dalam use case diagram memodelkan masukan ke sistem dan keluaran dari sistem. Use case diagram terdiri atas diagram untuk use case dan aktor. Use case diagram pada Aplikasi Kamus Bahasa Bima-Bahasa Indonesia Menggunakan Algoritma Levensthein Distance Sebagai Spell Checker Berbasis Android adalah sebagai berikut.

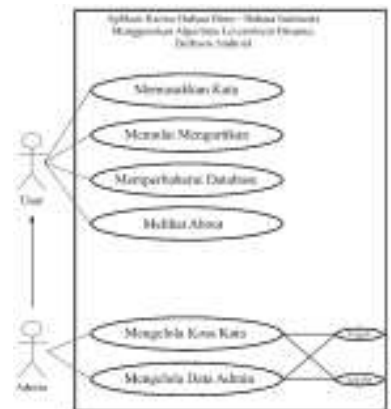

Gamabar 3. Use Case Diagam Aplikasi

\section{f. Activity Diagram}

Activity Diagram adalah Teknik untuk menggambarkan logika procedur, proses bisnis dan jalur kerja. Activity diagram menggambarkan alur aktivitas dalam sebuah sistem yang sedang dirancang dan bagaimana masing-masing alur aplikasi dapat berjalan. Berikut merupakan activity diagram dari masing-masing proses.

\section{Perancangan Perangkat Lunak}

Perancangan peranglat lunak merupakan tahap selanjutnya setelah melakukan analisis perangkat lunak. Rancangan perangkat lunak yang dibuat, nantinya akan menjadi panduan pengembangan pada tahap implementasi. Pada tahap ini dipaparkan mengenai batasan perancangan perangkat lunak, perancangan arsitektur perangkat lunak, perancangan struktur data perangkat lunak dan perancangan antarmuka perangkat lunak. Adapun bagian-bagian dari tahap perancangan perangkat lunak ini dapat dipaparkan sebagai berikut.

a) Batasan Perancangan Perangkat Lunak

Adapun batasan perancangan perangkat lunak pada Aplikasi Kamus Bahasa Bima - Bahasa Indonesia Menggunakan Algoritma Levensthein Distance Sebagai Spell Cheker Berbasis Android ini dapat dipaparkan sebagai berikut. (1) Aplikasi dapat melakukan penerjemahan dua arah yaitu Bahasa Bima - Bahasa Indonesia dan Bahasa Indonesia Bahasa Bima. (2) Hasil terjemahan dari Bahasa Bima ke Bahasa Indonesia yaitu Bahasa Indonesia. (3) Hasil terjemahan dari Bahasa Indonesia ke Bahasa Bima yaitu Bahasa Bima. (4) Terjemahan untuk kata yang merupakan sebuah nama, istilah khusus, kata khiasan, kata ungkapan, dan kata perulangan, hasilnya terbatas dan kemungkinan tidak sesuai. (4) Daftar kata yang digunakan sebagai database sebanyak \pm 2.000 baris. Dataset bersumber dari buku kamus dan website yang dibuat oleh para bloger. (5) Hasil terjemahan bersifat apa adanya dan akan terdapat beberapa awalan dan akhiran yang tidak sesuai. (6) Aplikasi dijalankan pada sistem operasi Android versi 5.0 ke atas. (7) Perancangan Arsitektur Perangkat Lunak

b) Perancangan arsitektur perangkat lunak

Pada Aplikasi Kamus Bahasa Bima-Bahasa Indonesia Menggunakan Algoritma Levensthein Distance Sebagai Spell Cheker Berbasis Android akan mengguanakan arsitektur client-server. Fungsi dari server adalah untuk menyimpan database yang digunakan oleh aplikasi smartphone melalui jaringan internet.

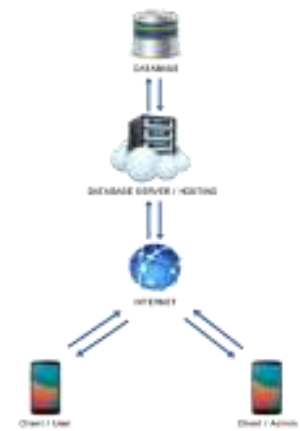

Gambar 4. Rancangan Arsitektur Perangkat Lunak

Disini pengguna dan admin dapat menggunakan database lokal secara offline namun ketika terdapat pembahruan database oleh admin maka admin akan menggunakan jaringan koneksi untuk pembahruan database. Sehingga database yang diperbahrui ini dapat digunakan oleh pengguna jika pengguna melakukan update database yang telah perbahrui oleh admin tetapi jika pengguna tidak memperbahrui database tersebut, pengguna juga masih dapat menjalankan aplikasi ini dengan database local yang lama.

c) Perancangan Struktur Data Perangkat Lunak

Perancangan struktur data perangkat lunak merupakan tahap pendefinisian dari kebutuhan-kebutuhan fungsional dalam suatu tahap pengembangan sistem. Aplikasi akan menggunakan SQLite database dan dikelola menggunakan software SQLiteBrowser.

d) Perancangan Antarmuka Perangkat Lunak

Berikut ini merupakan rancangan antarmuka Aplikasi Kamus Bahasa Bima-Bahasa Indonesia Menggunakan Algoritma Levensthein Distance Sebagai Spell Cheker Berbasis Android yaitu: (1) Rancangan Antarmuka Splash Screen, (2) Rancangan Antarmuka Menu Utama, (3) Rancangan Antarmuka Halaman, (4) Rancangan Antarmuka Halaman Hasil Terjemahan (5) Rancangan Antarmuka Usul Kata (6) Rancangan Antarmuka Login Administrator (7) 
Rancangan Antarmuka Daftar Kosakata, (8) Rancangan Antarmuka Ubah Password (9) Rancangan Antarmaku About (tentang).

4. Implementasi Perangkat Lunak

Implementasi perangkat lunak pada Aplikasi Kamus Bahasa Bima-Bahasa Indonesia Menggunakan Algoritma Levensthein Distance Sebagai Spell Checker Berbasis Android ini terdiri dari lingkungan implementasi perangkat lunak, batasan implementasi perangkat lunak, implementasi arsitektur perangkat lunak, implementasi struktur data perangkat lunak, implementasi layar antarmuka perangkat lunak.

A. Lingkungan Implementasi Perangkat Lunak

1. Spesifikasi Perangkat Lunak

Aplikasi Kamus Bahasa Bima - Bahasa Indonesia Menggunakan Algoritma Levensthein Distance Sebagai Spell Checker Berbasis Android dikembangkan menggunakan beberapa perangkat lunak sebagai berikut.
a) Sistem Operasi Windows 10 Pro 64-bit
b) Sistem Operasi Android Versi 5.0
c) Android Studio
d) SQLite Browser
e) Android Emulator
f) Addobe Photoshop
g) Balsamiq
h) Addobe Dreamweaver

2. Spesifikasi Perangkat Keras

Aplikasi Kamus Bahasa Bima-Bahasa Indonesia Menggunakan Algoritma Levensthein Distance Sebagai Spell Checker Berbasis Android dikembangkan menggunakan beberapa perangkat keras sebagai berikut.

1. Perangkat Komputer
a) Laptop Asus X441U
b) Processor Intel(R) Core(TM) i3-6006U CPU $2.00 \mathrm{GHz}$
c) RAM $4.00 \mathrm{~GB}$
d) Dilengkapi alat input dan output

2. Perangkat Andorid
a) Smartphone Xiomi Redmi Note 5 Pro
b) Resolusi $1090 \times 2160$ pixels
c) Snapdragon 636 Octa-Core $1,8 \mathrm{GHz}$
d) RAM 4 GB
e) Kamera $12 \mathrm{MP}$

B. Batasan Implementasi Perangkat Lunak

Batasan yang terdapat dalam implementasi perangkat lunak Aplikasi Kamus Bahasa Bima-Bahasa Indonesia Menggunakan Algoritma Levensthein Distance Sebagai Spell Checker Berbasis Android dijabarkan sebagai berikut.

1. Spesifikasi minimal yang diperlukan bagi perangkat Android untuk dapat menjalankan aplikasi yaitu, RAM 1GB, OS Android versi 5.0.
2. Aplikasi dapat melakukan penerjemahan dua arah yaitu dari Bahasa Bima ke Bahasa Indonesia dan dari Bahasa Indonesia ke Bahasa Bima.

3. Aplikasi dapat memeriksa kesalahan pengetikan pada kata yang dimasukan oleh pengguna menggunakan levensthein distance serta menampilkan rekomendasi kata yang mungkin dimaksud oleh pengguna.

4. Hasil terjemahan bersifat apa adanya.

5. Daftar kata yang digunakan sebagai database sebanyak \pm 2.000 baris. Dataset bersumber dari buku berupa kamus yang berjudul Kamus Bahasa BimaInggris-Indonesia 2.000 Kata yang ditulis Abdul Rafai H. Majid.

C. Implementasi Arsitektur Perangkat Lunak

Berdasarkan perancangan arsitektur perangkat lunak Aplikasi Kamus Bahasa Bima - Bahasa Indonesia Menggunakan Algoritma Levensthein Distance Sebagai Spell Checker Berbasis Android, untuk dapat melakukan proses yang diinginkan maka diimpplementasikan Activity dan juga beberapa Source Code.

D. Implementasi Struktur Data Perangkat Lunak

Berdasarkan perancangan structural data perangkat lunak Aplikasi Kamus Bahasa Bima - Bahasa Indonesia Menggunakan Algoritma Levensthein Distance Sebagai Spell Checker Berbasis Android yaitu untuk dapat menampilkan proses maka diimplementasikan Layout dan File yang tedapat pada proses pembuatan aplikasi.

E. Implementasi Layar Antarmuka Perangkat Lunak

Implementasi layer antarmuka terdiri atas antarmuka pada aplikasi pengguna dan juga antarmuka pada aplikasi admin. Berikut ini beberapa implementasi layar antarmuka Aplkasi Pengguna dan Aplikasi Admin.

1. Impelemtasi Splash Screen Aplikasi Pengguna Splash screen adalah tampilan awal yang hanya tampil sebentar ketika aplikasi dijalankan. Fungsi dari splash screen ini biasanya untuk menampilkan informasi yang bersifat sekilas.

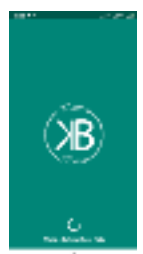

Gambar 5. Splash Screen Aplikasi Pengguna

2. Impelentasi Menu Utama Halaman Terjemahan Aplikasi Pengguna

Pada halaman Menu Utama Halaman Terjemahan sesuai dengan namanya yaitu tampilan yang berisikan menumenu dan sebagai halaman terjemahan dari Aplikasi Kamus Bahasa Bima-Bahasa Indonesia Menggunakan Algoitma 
Levensthein Distance Sebagai Spell Checker Berbasis Android.

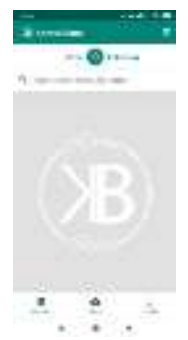

Gambar 6. Menu Utama Halaman Terjemahan Aplikasi Pengguna

3. Implementasi Hasil Terjemahan

Pada halaman Implementasi Hasil Terjemahan sesuai dengan namanya yaitu yang berisikan hasil terjemahan dan rekomendasi kata terjemahan dari Aplikasi Kamus Bahasa Bima - Bahasa Indonesia Menggunakan Algoritma Levensthein Distance Sebagai Spell Checker Berbasis Andorid.

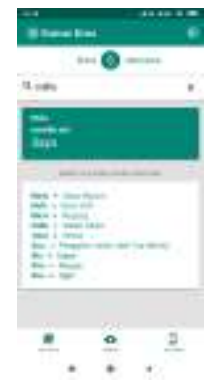

Gambar 7. Hasil Terjemahan

4. Implementasi Halaman Login Aplikasi Admin

Login Admin akan ditampilkan setiap aplikasi admin dijalankan. Tujuannya adalah untuk mencegah agar pengguna yang selain admin tidak dapat mengakses data sembarangan. Pada antarmuka Halaman Login, Admin akan diminta untuk memasukkan username dan password sebelum menggunakan aplikasi.

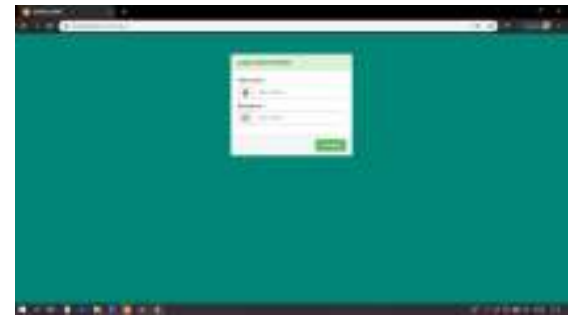

Gambar 8. Halaman Login Aplikasi Admin

5. Implementasi Halaman Utama Daftar Kosakata Aplikasi Admin

Pada halaman Menu Utama Daftar Kosakata sesuai dengan namanya yaitu tampilan yang berisikan menu-menu yang menjadi fitur-fitur utama dari Aplikasi Kamus Bahasa Bima - Bahasa Indonesia Menggunakan Metode Levenshtein Distance Sebagai Spell Checker Berbasis Android untuk aplikasi admin.

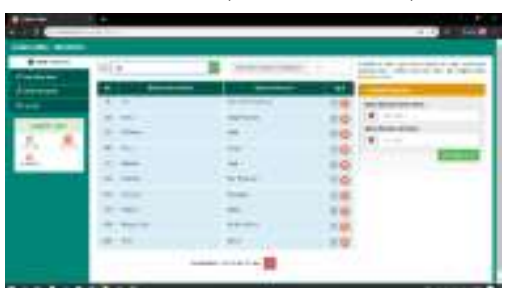

Gambar 9. Halaman Utama Daftar Kosakata Aplikasi Admin

5. Pengujian Perangkat Lunak

a. Tujuan Pengujian Perangkat Lunak

Tujuan pengujian perangkat lunak pada Aplikasi Kamus Bahasa Bima-Bahasa Indonesia Menggunakan Algoritma Levensthein Distance Sebagai Spell Checker Berbasis Android, yaitu: (1) Menguji kebenaran alur proses berdasarkan antarmuka pada Aplikasi Kamus Bahasa BimaBahasa Indonesia Menggunakan Algoritma Levensthein Distance Sebagai Spell Checker Berbasis Android. (2) Menguji penggunaan Aplikasi Kamus Bahasa Bima-Bahasa Indonesia Menggunakan Algoritma Levensthein Distance Sebagai Spell Checker Berbasis Android pada beberapa smartphone yang berbeda. (3) Mengetahui tingkat akurasi Aplikasi Kamus Bahasa Bima - Bahasa Indonesia Menggunakan Algoritma Levensthein Distance Sebagai Spell Checker Berbasis Android dalam melakukan penerjemahan serta penerapan metode yang digunakan. (4) Mengetahui penilaian dari ahli dan respon dari pengguna setelah mengunakan Aplikasi Kamus Bahasa Bima-Bahasa Indonesia Menggunakan Algoritma Levensthein Distance Sebagai Spell Checker Berbasis Android.

1) Pengujian Fungsional (Black Box Testing)

Pengujian dilakukan dengan mendefinisikan kondisi input dan melakukan testing terhadap spesifikasi fungsional dari aplikasi. Teknik ini hanya melihat keluaran yang dihasilkan dari data atau kondisi input yang diberikan untuk fungsi yang ada tanpa melihat bagaimana proses untuk mendapatkan keluaran tersebut.

2) Tujuan Pengujian Struktural (White Box Testing)

White box testing merupakan pengujian yang didasarkan pada pengecekan terhadap detail perancangan, menggunakan struktur kontrol dari desain program secara prosedural untuk membagi pengujian ke dalam beberapa test case. Test case dilakukan untuk memastikan bahwa semua statement pada program telah dieksekusi paling tidak satu kali dan bahwa semua kondisi logis telah diuji. White-box testing digunakan untuk mengetahui cara kerja perangkat lunak secara internal.

3) Tujuan Pengujian Tingkat Akurasi

Pengujian tingkat akurasi merupakan pengujian terhadap ketepatan hasil yang diperoleh dari penerapan metode yang digunakan. Pengujian ini dilakukan untuk mengetahui kebenaran hasil dari pengimplementasian metode, dengan melihat referensi sebagai pedoman untuk input dataset yaitu 
sebuah buku kamus yang digunakan berjudul "Kamus Bahasa Bima - Inggris - Indonesia 2.500 Kata" yang di tulis oleh Abdul Rifai H. Majid atau sering di panggil Dae Fa'i.

4) Tujuan Pengujian Ahli Media dan Pengguna

Pengujian Ahli Media berfokus pada penilaian terhadap kelayakan aplikasi, yang bertujuan untuk memperoleh kesimpulan bahwa aplikasi siap untuk uji coba lapangan atau tidak.

b. Tata Ancang dan Teknik Pengujian Perangkat Lunak

Tata ancang dan teknin pengujian perangkat lunak Aplikasi Kamus Bahasa Bima-Bahasa Indonesia Menggunakan Algoritma Levensthein Distance Sebagai Spell Checker Berbasis Android yaitu: (1) Dilakukan dengan menjalankan aplikasi, kemudia dalam penggunaannya dilihat kesesuaian kondisi-kondidi yang dibuat, aplikasi dapat berjalan dengan sebagaimana mestinya sesuai rancangan antarmuka yang telah dirancang sebelumnya, serta meminimalisir terjadinya error. Setelah semua proses dapat dijalankan maka hasil dari pengecekan tersebut digambarkan dalam sebuah angket kesesuaian proses kerja aplikasi.(2) dilakukan dengan menjalankan aplikasi pada beberapa perangkat smartphone yang berbeda oleh beberapa orang pengguna, melihat kesesuaian kondisi-kondisi yang dibuat, serta aplikasi dapat berjalan dengan sebagaimana mestinya sesuai rancangan antarmuka. Kemudian hasil dari pengecekan tersebut digambarkan dalam sebuah angket kesesuaian proses kerja aplikasi utuk setiap pengguna.(3) dilakukan dengan memberikan kesempatan kepada beberapa pengguna untuk menggunakan aplikasi. (4) dilakukan dengan cara memberikan kesempatan kepada ahli maupun pengguna untuk menggunakan aplikasi dengan dampingan serta arahan dari peneliti atau pembuat aplikasi. Setelah itu, setiap ahli maupun pengguna diminta untuk mengisi angket yang telah disiapkan dengan pendapat masing-masing.

Presentase nilai $=\frac{\text { Jumlah hasil sesuai }}{\text { Jumlah butir uji }} \times 100 \%$

Gambar 10. Pehitungan Uji Ahli Media

Setelah melakukan perhitungan terhadap angket uji Ahli Media serta memperoleh hasil berupa presentase nilai kesesuaian, selanjutnya hasil pengujian yang didapat dinilai berdasarkan kriteria penilaian sebagai berikut.
a) Angka 0\%-19,99\%
$=$ Sangat Tidak Layak
b) Angka 20\%-39,99\%
= Tidak Layak
c) Angka $40 \%-59,99 \%$
= Cukup Layak
d) Angka $60 \%-79,99 \%$
= Layak
e) Angka $80 \%-100 \%$
$=$ Sangat Layak

c. Evaluasi Hasil Pengujian Perangkat Lunak
Berdasarkan pengujian perangkat lunak yang telah dilaksanakan, maka evaluasi hasil pengujian perangkat lunak pada Aplikasi Kamus Bahasa Bima-Bahasa Indonesia Menggunakan Algoritma Levensthein Distance Sebagai Spell Checker Berbasis Android dijabarkan sebagai berikut.

Setelah melakukan pengujian fungsional (black box testing) pada aplikasi oleh 5 orang penguji dengan smartphone yang berbeda-beda, hasilnya adalah semua proses sesuai atau semua proses berhasil berjalan dengan baik di berbagai smartphone yang berbeda. Tidak ada perbedaan fungsi dan tampilan untuk setiap smartphone masing-masing penguji pada saat menjalankan atau menggunakan aplikasi. Selanjutnya pada pengujian struktural (white box testing), hasilnya menyimpulkan bahwa proses kerja perangkat lunak secara internal bekerja dengan baik sesuai dengan spesifikasi yang telah ditetapkan. Source code program bekerja dengan baik dan benar sesuai dengan fungsinya masing-masing.

Pengujian ahli media yang telah dilakukan oleh 2 orang ahli, hasilnya menyatakan bahwa Aplikasi Kamus Bahasa Bima - Bahasa Indonesia Menggunakan Algoritma Levensthein Distance Sebagai Spell Checker Berbasis Android sangat layak dengan persentase keseluruhan penilaian yaitu $100 \%$. Penilaian dari segi tampilan aplikasi juga sebesar $100 \%$. Hasil tersebut diperoleh setelah menindak lanjut saran perbaikan dari ahli, yaitu perbaikan menu download menjadi menu unduh serta terdapat saran untuk pengembangan selanjutnya yaitu diharapkan menambahkan google voice, pengucapan dari bahasa yang dimaksud dan rekomendasi pengusulan kosa kata pada aplikasi. Perhitungan hasil uji ahli media dapat dilihat pada Lampiran 6.

Setelah aplikasi dinyatakan layak pada pengujian ahli media, dilakukan pengujian untuk mengetahui penilaian pengguna terhadap Aplikasi Kamus Bahasa Bima - Bahasa Indonesia Menggunakan Algoritma Levensthein Distance Sebagai Spell Checker Berbasis Android. Pengujian melibatkan 15 orang pengguna dari kalangan masyarakat umum. Pengujian dilakukan menggunakan angket penilaian UEQ (User Experience Questionnaire). Setelah pengujian dilakukan, diperoleh hasil sebagai berikut. Butir penilaian menggunakan skala dari -3 hingga +3 , dimana -3 merupakan jawaban paling negative, 0 merupakan jawaban netral, dan +3 merupakan jawaban paling positif. Nilai dengan skala di atas +1 menunjukan kesan positif dari pengguna terhadap aplikasi, sedangkan nilai dengan skala di bawah -1 menunjukan kesan negative. Perhitungan hasil angket UEQ dapat dilihat pada Lampiran 9.

Berdasarkan perhitungan angket UEQ tersebut diperoleh hasil antara lain: dari segi daya tarik aplikasi tergolong sangat baik, dari segi kejelasan aplikasi sangat baik, dalam hal efisiensinya aplikasi sangat baik, ketepatan aplikasi sangat baik, stimulasi aplikasi sangat baik, dan dari segi kebaruan juga dinyatakan sangat baik. Rata-rata pencapaian User Experience berada pada tingkatan yang sangat memuaskan seperti tampak pada gambar berikut ini. 


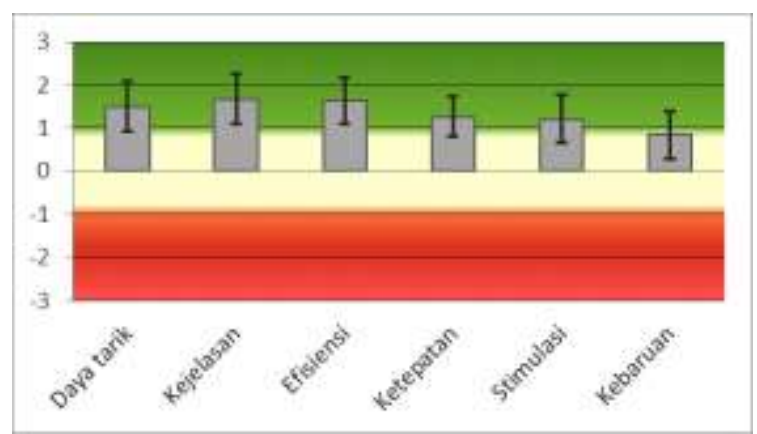

Gambar 11. Tingkat Pencapaian Hasil Uji UEQ

\section{B. PEMBAHASAN}

Algoritma pengembangan perangkat lunak pada Pengembangan Aplikasi Kamus Bahasa Bima - Bahasa Indonesia Menggunakan Algoritma Levensthein Distance Sebagi Spell Checker Berbasis Android ini mengacu pada model yang ada pada Software Development Life Cycle (SDLC). Model SDLC yang digunakan dalam pengembangan penelitian ini adalah model waterfall dan pemodelannya menggunakan UML (Unified Modelling Language). Beberapa tahap penelitian yang dilakukan dalam penelitian ini yaitu bergerak maju mulai dari tahap analisis, perancangan, implementasi dan pengujian. Tahap analisis perangkat lunak merupakan tahap pertama dalam model waterfall yaitu tahap analisis kebutuhan (requirement analysis). Analisis kebutuhan dilakukan untuk mengetahui kebutuhan yang dibutuhkan dalam proses pengembangan. Perancangan perangkat lunak merupakan tahap selanjutnya setelah melakukan analisis perangkat lunak. Rancangan perangkat lunak yang dibuat, menjadi panduan pengembangan pada tahap implemntasi.

Pengembangan Aplikasi Kamus Bahasa Bima Bahasa Indonesia Menggunakan Algoritma Levensthein Distance Sebagi Spell Checker Berbasis Android, pada tahap implementasinya dikembangkan dengan menggunakan IDE (Integrated Development Environment) resmi dari Google yang dikembangkan dari IntelliJ yaitu Andorid Studio. Pengembangan Aplikasi Kamus Bahasa Bima - Bahasa Indonesia Menggunakan Algoritma Levensthein Distance Sebagi Spell Checker Berbasis Android menerapkan algoritma levensthein distance, yakni suatu matriks untuk mengukur jumlah perbedaan antara dua string. Dua buah string adalah jumlah minimum operasi yang dibutuhkan untuk mengubah satu string (source string) menjadi string lain (target string), dimana suatu operasi melibatkan penyisipan (insertion), penghapusan (deletion), dan penggantian (substitution) dari suatu karakter tunggal. Perhitungan jarak antara dua string ini ditentukan dari jumlah minimum operasi perubahan untuk membuat string A menjadi string B. Levensthein Distance dapat dikatakan algoritma sederhana karena mampu mengukur jarak antara dua string yang ukurannya tidak sama dengan menghitung jumlah pengoperasian yang perlu dilakukan untuk mengubah string yang satu menjadi string yang kedua yang diperbandingkan. Algoritma ini memberikan hasil perhitungan yang cukup maksimal sehingga dapat digunakan baik tetapi agak rumit karena mensimulasikan perhitungan melalu model matriks. Tujuannya adalah untuk memeriksa kesalahan pengetikan huruf/kata yang dimasukan oleh pengguna sehingga jika terdapat kesalahan pengetikan atau kata yang dimasukan tidak ditemukan pada database, maka aplikasi dapat menampilkan rekomendasi kata yang mungkin dimaksud oleh pengguna.

Pengembangan Aplikasi Kamus Bahasa Bima Bahasa Indonesia Menggunakan Algoritma Levensthein Distance Sebagi Spell Checker Berbasis Android telah berhasil dikembangkan dan telah melalui tahap pengujian. Pengujian respon pengguna terhadap aplikasi dinyatakan positif. Rata-rata pencapaian User Experience berada pada tingkat yang sangat memuaskan (excellent). Dari segi daya tarik aplikasi tergolong sangat baik, ketepatan aplikasi sangat baik, stimulasi aplikasi sangat baik, dan dari segi kebaruan juga dinyatakan sangat baik.

Berdasarkan hasil dari beberapa pengujian yang dilakukan dapat dinyatakan bahwa tujuan peneliti sudah tercapai. Hal tersebut dilihat dari uji fungsional (black box testing), uji struktural (white box testing), uji ahli media yang memiliki nilai 100\% "sangat layak", dan uji pengguna yang mendapatkan hasil yang sangat baik. Namun tidak lepas dari beberapa hal yang masih menjadi kekurangan dari aplikasi, seperti jumlah kosakata pada aplikasi yang terbatas. Aturanaturan yang terdapat pada penggunakan tanda petik (') masih perlu disempurnakan lagi pada bahasa Bima agar menghasilkan terjemahan yang lebih baik lagi. Tidak ada kendala yang cukup berarti yang dialami pada saat pengembangan aplikasi. Hanya memerlukan waktu yang lebih, khususnya pada saat pembuatan database. Selain itu, pemrograman Android yang selalu berkembang juga menjadi sebuah kendala karena membutuhkan waktu untuk kembali mempelajarinya dan menyesuaikan dengan ilmu yang diperoleh pada saat perkuliahan.

\section{SIMPULAN}

Berdasarkan analisis, perancangan, implementasi, dan pengujian yang telah dilakukan pada Pengembangan Aplikasi Kamus Bahasa Bima - Bahasa Indonesia Menggunakan Algoritma Levenshtein Distance Sebagai Spell Checker Berbasis Android, diperoleh kesimpulan sebagai berikut. (1) Aplikasi telah berhasil dikembangkan dengan menggunakan metode pengembangan perangkat lunak yang mengacu pada model yang ada pada metode pengembangan Software Development Life Cycle (SDLC). Model SDLC yang digunakan dalam pengembangan penelitian ini adalah model waterfall dan pemodelannya menggunakan diagram UML (Unified Modelling Language). Tahapan yang dilakukan yaitu bergerak maju mulai dari tahap analisis, perancangan, implementasi dan pengujian. (2) Respon pengguna terhadap aplikasi dinyatakan positif. Rata-rata pencapaian User 
Experience berada pada tingkatan yang sangat memuaskan (excellent). Dari segi daya tarik aplikasi tergolong sangat baik, dari segi kejelasan aplikasi sangat baik, dalam hal efisiensinya aplikasi sangat baik, ketepatan aplikasi sangat baik, stimulasi aplikasi sangat baik, dan dari segi kebaruan juga dinyatakan sangat baik.

Berdasarkan hasil penelitian, pengembangan, dan kesimpulan yang telah dipaparkan sebelumnya, terdapat beberapa saran untuk penelitian selanjutnya antara lain sebagai berikut. (1) Aplikasi agar lebih dikembangkan lagi dengan menambahkan fitur penerjemahan kalimat bahasa Bima bahasa Indonesia. (2) Aplikasi agar lebih dikembangkan lagi dengan menambahkan fitur-fitur seperti text to speech dan menampilkan teks dalam bentuk aksara Bima. (3) Aplikasi membutuhkan penyempurnaan dalam hal penerjemahan dengan penggunaan metode serta aturan-aturan yang lebih tepat agar hasil penerjemahan menjadi lebih sempurna. Salah satunya yang perlu diperjelas yaitu aturan untuk penggunaan tanda petik (") seperti kata "nae" dengan "na'e" pada teks bahasa Bima. Serta penggunakan kata benda, kata kerja, kata sifat dan lain sebagainya. (4) Aplikasi memerlukan daftar kosakata yang lengkap agar keberhasilan dalam menerjemahkan kata menjadi lebih meningkat.

\section{REFERENSI}

[1] Abdul, K. (2003). Pengenalan Sistem Informasi . Yogyakarta: Andi.

[2] Annisa, Riski. 2017. "Perancangan Kamus Istilah Akuntansi Berbasis Desktop Dengan Metode Interpolation Search". Jurnal Evolusi Volume 5 No 1.

[3] Budiman, H. (2014). Buku Pintar Gadget Android untuk Pemula. Jakarta: Kunci Komunikasi.

[4] Gumilar, S., Munir, M., \& Susrama, I. (2012). Sistem Informasi Akademik Pada Paud Nur Insani Surabaya Berbasis Web. 1-2..

[5] Irna Rahayu, B. P. (2015). IMPLEMENTASI KAMUS KEDOKTERAN DENGAN METODE INTERPOLASI (INTERPOLATION) DAN MENCARI KEMIRIPAN KATA MENGGUNAKAN ALGORITMA LEVENSHTEIN DISTANCE PADA PERNGKAT ANDROID. semanTIK, 35-45.

[6] Jogiyanto. (1999). Analisis dan Disain Sistem Informasi Pendekatan Terstruktur Teori dan Praktek Bisnis. Yogyakarta: Andi.

[7] Kadir, A. (2005). Dasar Pemrograman Web dengan $A S P$. Yogyakarta: Andi Yogyakarta.

[8] Na'firul Hasna Ariyani, S. R. (2016). APLIKASI PENDETEKSI KEMIRIPAN ISI TEKS DOKUMEN MENGGUNAKAN METODE LEVENSHTEIN DISTANCE. SEMANTIK, 279-286

[9] Resmawan, K. T. (2015). engembangan Aplikasi Kamus dan Penerjemah Bahasa Indonesia - Bahasa Bali Menggunakan Metode Rule Based Berbasis Android. KARMAPATI, 78-81.

[10] Wirayasa, I. P. (2018). PENGEMBANGAN APLIKASI PENERJEMAH BAHASA INDONESIA BAHASA BALI MENGGUNAKAN METODE. Karmapati, 1-5 